\title{
INTRODUCTION \\ Migration, Development, and Social Transformation
}

Nina Glick Schiller and Thomas Faist

How should scholars interested in social analysis approach the topic of migration and development, and with what analytical tools, conceptual framework, or political stance? The topic of migration and development is becoming an important field of study, yet these questions are too rarely asked. In this special section, "Migration, Development, and Transnationalization: A Critical Stance," all six authors, each in his or her own way, and from various intellectual and disciplinary starting points, argue that the assumptions and paradigms underlying the study of the asymmetrical but mutual transfers of resources that accompany migration are deeply flawed and continue to reflect the interests of the global North, the most powerful states, and the globe-spanning institutions that serve their interests. The articles explore the role that contradictory discourses about migration are playing as modes of explanation for growing inequalities and an expanding global regime of militarized surveillance. Moreover, the articles provide useful alternative perspectives to the current received wisdom about the relationship between migration and development.

The approaches to the topic advocated in this special section both reflect and reflect on the current historical conjuncture. There has been a recent global financial downturn in which migrants, as Isotalo (this issue) points out, are among the most vulnerable. Yet migrants are seen as vital agents of international development by international financial institutions such as the World Bank, the European Union and its member states, international organizations from the United Nations, and a myriad of non-governmental organizations. For example, a United Nations Development Programme report, Overcoming Barriers: Human Mobility and Development (UNDP 2009: 3), argues that migrants "boost economic output, at little or no cost to locals. Indeed, there may be broader positive effects ... In migrants' countries of origin ... [m] oving generally brings benefits, most directly in the form of remittances sent to immediate family members. However, the benefits are also spread more broadly as remittances are spent-thereby generating jobs for local workers-and as behaviour 
changes in response to ideas from abroad. Women, in particular, may be liberated from traditional roles."

The new tendency of powerful financial and global governance institutions to highlight the positive agency of migrants and renew a discourse of migration and development followed the unleashing of neo-liberal market forces and the dramatic growth in economic and social disparities in many places in the world. In response, "[f] aced with the deepening asymmetries between developed and underdeveloped countries, the increase of social inequalities among national populaces, and a diversity of social conflicts, the promoters of neo-liberal globalization have resumed the discourse of development. Far from proposing structural and institutional changes, however, this just seeks to provide neo-liberalism with a 'human face'” (Delgado Wise and Márquez Covarrubias, this issue; see also Faist, this issue). As the Washington Consensus fades, liberal rhetorics of democracy and freedom are increasingly and more openly accompanied or replaced by the use of military force and repression.

In this issue, Isotalo examines the relationships among mobility, discourses about human security, and the threat of terrorism, and Delgado Wise, Márquez Covarrubias, and Glick Schiller highlight migration in terms of the continuation of forms of imperialism. Placing the current revival of development narratives within an analysis of neo-liberalism and its discontents and contradictions helps the authors in this special section make sense of the anti-immigrant discourses and regulatory regimes that are concurrent with the celebration of migrants as agents of development. Glick Schiller and Isotalo address the resurgence of an interest in migration and development at a time when the movement of people, whether under the rubric of labor or of refugees, is increasingly restricted.

Scholars, political leaders, and policy makers have been discussing the relationship between migration and development for a long time, but with changing analytical tools, conceptual frameworks, political stances, and conclusions. At the beginning of the Industrial Revolution-with varying timing in different regions of Europe-political rulers tried to restrict workers from migrating across the borders of states. Passports were used to retain labor rather than to restrict its influx (Torpey 2000). In those cases, the links between migration and development were acknowledged, but the emphasis was on the ways in which migrants enriched the receiving state. The retention of labor was thought essential for the economic development and prosperity of the state of origin of the would-be migrants. On the other hand, the fact that the development of Europe depended on profits made from enslaved, indentured, and colonized migratory labor in other regions of the world has been too rarely acknowledged in European discourses about development. The wealth of the welfare state regimes that attract migrants to the North came in the past and continues to be built, in part, on migratory labor.

During the period of the African slave trade and European colonialism of the nineteenth and twentieth centuries, the development of the wealth and power of colonizing states was dependent on the controlled movement of labor in various colonies. At the end of the nineteenth century, as the academic disciplines became distinctive enterprises, separated from philosophy and theology, 
the conceptual frameworks for the discussion of migration and development also became more clearly articulated in ways that have continued to shape how we think about these fields.

First, there was a discursive shift from a concern with the mobility of people to a concern with the development of nation-states and thus also the control of flows across national borders. As Glick Schiller points out (this issue), the founders of geography, including Ratzell, initially approached migration without a national lens, concerned primarily about the relationship between the movement of people and the distribution of resources. However, Ratzell soon developed a political geography that located emotive power in the development, well-being, and expansion of the state. E. G. Ravenstein (1885), considered a founder of geography and migration studies, expounded "laws of migration," such as "migration increases as industries and commerce develop and transport improves" (ibid.: 178; cf. Ravenstein 1889). Ravenstein used British national data and raised questions about national development. Yet he was concerned with both internal and international migration, which allows for units of analysis such as rural/urban and rich/poor regions, thus differentiating his scholarship from the methodological nationalist orientation that characterizes much of recent migration scholarship.

By jettisoning methodological nationalism, an orientation that makes the nation-state the unit of analysis, scholars of migration and development are better able to examine differences of power within states and regions and around the globe. By not confining analyses within the borders of particular states, they can better explore the very uneven patterns of internal and international migration, remittance investment, class formations, knowledge, flows of capital, and infrastructure development. A critique of methodological nationalism does not start from a borderless or boundaryless world. Rather, it focuses on the very constitution of (state) borders and boundaries and their effect on the creation of inequalities between categories of persons within transnational processes of the production of wealth and various forms of power.

During the twentieth century, the social sciences became increasingly entwined not only with the nation-state as a unit of analysis but also with a concern for the well-being of a scholar's own national state. Migration scholars increasingly focused on the question of whether or not migration benefited the nation-state. They became concerned not only with economic development but also with the social cohesion of particular nation-states. Thus, they ignored the broader forces and legacies of colonialism and the processes of capital accumulation, concentration, and destruction that continually restructure industrial development, place, and the movements of people on a global scale. Despite a preoccupation with nation-state building, at the beginning of the twentieth century, migration scholars did initially acknowledge the transnational nature of the migration process. In their classic work, The Polish Peasant in Europe and America, William Thomas and Florian Znaniecki ([1918-1920] 1958) argued for strengthening what nowadays would be called the "transnational ties' of Polish migrants in the United States back to Poland by supporting agricultural cooperatives. By World War II, this transnational perspective on 
migration had been abandoned. Its recent resurgence and adoption by development scholars goes beyond the acknowledgment of mutual connections and influences to an argument that transnational ties inevitably produce win-win situations, that is, the benefits of transnational migration for both the sending and the receiving states.

This simplistic reading of migrants' transnationality has recently become apparent in migration and development scholarship, as can be seen in UNDP (2009). At the same time, most migration scholars based in the United States and Europe today portray migrants as a potential destabilizing force. They have revived past images of migrants as bearers of political (i.e., anarchistic, revolutionary), cultural, or religious difference. The language of difference once again globally encompasses those who move within discourses of securitization. Isotalo, for example, documents the resurgent politics of fear that increasingly equates human mobility and the flights from war, destruction, disaster, or economic collapse with terrorism.

Researchers who are critical of this perspective have repeatedly noted that the attribution of difference to the migrant foreigner has served to reinforce national identities, unities, and borders. As Fredrik Barth (1969) and a multitude scholars of identity have noted, borders and boundaries construct as well as mark cultural differences (Brubaker 2004; Sollors 1989). By taking a critical stance toward most migration and development narratives, the articles in this special section address the significance of portraying migrants as threats to the peace and security of nation-states, while simultaneously depicting them as heroic agents of development.

\section{From the Migration-Development Mantra to the Migration-Development Nexus}

Today, after years of low priority in academic and, above all, public debates, the link between migration and development has emerged again. Migration has mutated from being a problem for economic development to being a solution. In other words, the claim that development failure produces international migration has given way to the 'new mantra' that migration-that is, migrants-may help to advance economic development in their countries of origin (Kapur 2004). Thus, the traditional focus in migration studies on the causes and consequences of population movements has shifted to a focus on the types of migrants and migration that will promote development (for a detailed analysis, see Faist 2008). Hopes are pinned on labor migrants, especially temporary ones, sending financial remittances to their countries and locales of origin.

International organizations and governments of the Organisation for Economic Co-operation and Development (OECD) have renewed calls for schemes of temporary migration, presently referred to as 'circular migration'. These same authorities argue that the 'highly skilled' are transferring their expertise from North to South and from West to East ('brain gain'), rather than furthering the depletion of 'talent' in the South ('brain drain'). Discussions have focused 
both on individual persons who remit resources and on settled migrants in diasporas, who engage in collective financial remittances into selected development projects (e.g., infrastructure, health, education) and who facilitate 'social remittances', such as the transfer of human rights, gender equity, and democracy from North to South.

In short, certain policy circles in international agencies and state governments now maintain that facilitating certain types of population mobility will lead to development. Generally, they argue that migrant remittances from receiving to sending countries could spur development in the long run. This view can be called, following a critical appraisal of such ideas, the 'migration-development mantra'. This viewpoint, however, is very different from the 'migration-development nexus'. It is important to note that the idea that migration and development are correlated and that economic development usually leads to more, rather than less, emigration-the insights of classical migration research into the migration-development nexus-is not equivalent to the notion that certain types of population mobility induce development, which is the claim made by policy makers and academics since the early 2000s.

Clearly, it is important to dig deeper and to connect this debate with the far-reaching societal changes and social transformations that are affecting both migration and development. We need to go beyond the current infatuation with the idea of international migration as a panacea for development. It helps to start with a simple observation, a foundational point that is made in the articles by Raúl Delgado Wise, Humberto Márquez Covarrubias, and Binod Khadria: the agenda for the migration-development mantra is firmly set by the countries in the North or West, while the supposed beneficiaries are the countries in the South or East.

The debate on migration and development that has emerged over the past half-dozen years is one of several to have occurred since the 1960s. In all cases, the policy and academic debates are overwhelmingly driven by Northern governments and have originated in international organizations such as the World Bank, which are governed by Northern majorities. In this asymmetric debate, it is important to point out that those in the South are not equals in setting principles and priorities. They are partners only in implementation.

That the Northern macro-agents set the agenda is obvious in various documents produced by institutions with global claims, such as the 2005 report of the Global Commission on International Migration. This report emphasizes not only the importance of financial remittances and ways to reduce transfer costs, but also the need for more highly skilled labor in OECD countries, and calls for new schemes of circular migration (GCIM 2005). Promoted by international organizations and Northern governments, the United Nations High-Level Dialogue on Migration and Development of 2006 was held "to discuss the multidimensional aspects of international migration and development in order to identify appropriate ways and means to maximize its development benefits and minimize its negative impacts." ${ }^{1}$ By contrast, the governments of developing or transformation countries, such as the Philippines, no longer officially regard migration as a pillar of their formal development policy, if they ever did. 
The new enthusiasm closely resembles that of the 1960s, when sending countries such as Turkey looked forward to receiving financial remittances, return migrants with Western work ethics, and the transfer of valuable skills. In the first regard, financial remittances now stand, as they did in the 1960s, at the core of hopes. Until the 2008 economic collapse, there had been a sharp increase in remittances over the past several years, up by almost 100 percent between 1999 and 2004, an amount at least twice as high as official development aid. Secondly, in the 1960s, migrants were supposed to transfer the right kind of work ethics 'back home'. Nowadays, migrants are also depicted as bearers of Western values, called 'social remittances', meaning that they are thought of as brokers for ideas such as gender equity and democratization. Thirdly, the 1960s concept that migrants were supposed to transfer skills has resurfaced within the concept of human capital. Today's discussions differ only in the ever-increasing centrality of financial remittances, which have emerged as a form of securities market, and the focus on circular migration (Guarnizo 2003; Vertovec 2007). There is something for all agents involved who push the mantra. The World Bank (2006) focuses on individual remittances and thus also defines remittances as transfers by individuals, while development organizations tend to look at collective remittances by migrant associations, such as-at least in United States-the ubiquitous emphasis on hometown associations.

As Thomas Faist (this issue) points out, between the 1960s, when the argument that migration spurs development was prevalent, and today, there was an intervening period in which development experts claimed that the causality of the nexus ran in the opposite direction. Underdevelopment caused migration, and migration contributed to underdevelopment, especially through mechanisms such as brain drain. During much of the 1980s and part of the 1990s, the view prevailed that migration undermines the prospects for local economic development, resulting in a state of stagnation and dependency.

Arguing that the rapid growth of financial remittances to less-developed countries could help spur economic development, the World Bank (2002) initiated the latest support for migrants as agents of development. Subsequently, various development agents have projected the following additional benefits: (1) migrants will transfer both financial and social remittances; (2) the brain drain will gradually be replaced by a brain gain; (3) temporary (and circular) migration will stimulate development; (4) migrant diasporas will become development agents, in addition to individual migrants; and (5) economic development will eventually reduce emigration, although there will be an increase ('migration hump' or s-shaped migration curve) in the short and middle term. At present, the evidence for each and every one of these projected benefits is still very weak (Siddiqui 2005). For example, it all depends on whether remittances contribute to rising or declining income inequality.

In sharp contrast, Khadria, Delgado Wise, and Márquez Covarrubias (this issue) insist that any balanced view of the effects of migration must look not only at flows of resources from immigration countries back to emigration regions but also at flows running in the opposite direction. This would entail 
the much-debated brain drain, the costs of international migration, and the considerable expenses required in the attempt to obtain legal status in the immigration countries (Nolin 2006). As migration policies become increasingly and selectively restrictive, it stands to reason that irregular migrants have to invest ever more resources to legalize their status. This is one reason why claims that financial remittances have increased dramatically over the past decade have to be viewed cautiously. In sum, one would need to take a comprehensive look at the two-way flows of investment in migrants and remittances in order to gauge the economic potential of migrant transfers.

\section{The Migration-Development Nexus and Social Transformation}

Against this backdrop, the articles in this special section of Social Analysis strive to focus on processes of social transformation in order to understand better and to contribute to the current round of discourse on the migrationdevelopment nexus. The authors step out of the debate, examine its foundational premises, find them flawed, and make suggestions to begin anew. They do not simply accompany their critique of the current state of affairs with calls for more research to confirm or refute or modify some of the assumptions listed above concerning the connection between migration and development, although this would also be a worthwhile task. Instead, given this state of affairs, "Migration, Development, and Transnationalization" approaches migration as an integral part of the processes of social transformation. Our authors take what Glick Schiller (this issue, forthcoming) has called a 'global perspective on migration'. This perspective, which offers a conceptual framework that includes inequalities between North and South, East and West, sees migrants as a major force in reshaping social and political formations.

The section opens with Nina Glick Schiller and Thomas Faist arguing specifically for such a global perspective. In "A Global Perspective on Migration and Development," Glick Schiller's focus is migration scholarship and the failure of scholars in this field to move beyond examinations of the role of migration in the development and social cohesion of specific nation-states. She calls attention to the failure of this scholarship to address the contradictory contemporary narratives that view migrants as agents of development but also as threats to the security and prosperity of nation-states.

Glick Schiller's global perspective on migration enables scholars to examine transnational fields of power within which migrant settlement and transnational connection occur in specific localities. This perspective does not deny the continuing role of nation-states of very different degrees of power in constituting a regulatory and surveillance regime that disciplines, restricts, and subordinates people trying to move within, as well as across, states. However, it allows for analytical space within which to examine the relationship between these states and broader globe-spanning networks of corporate and institutional power. To develop a global power perspective-which is an analytical stance, not a world systems or world society analysis-Glick Schiller argues that it is 
necessary to critique the methodological nationalism that has informed much of migration studies.

On the basis of this critique, Glick Schiller is able to note the emergence of a new global regime of labor exploitation that cannot be fully addressed within the rubric of migration and development. She warns that blithe descriptions and analysis of circulatory migration and transnational social connections that seem to be supportive of migrant mobility actually endorse a new global labor regime that denies rights and access to citizenship to most migrants. This regime, justified in the West through a defense of the 'welfare state', which dismisses the humanity of the migrant sector of the workforce, is corrosive to the aspirations for social and economic justice of citizens and non-citizens alike. However, exactly because the new endorsement of a transnational temporary labor regime is so contradictory, Glick Schiller suggests that the shared threats to human freedom it contains provide new bases for global perspectives on migration and common struggles for social transformation.

Thomas Faist's article, "Transnationalization and Development: Toward an Alternative Agenda," enters the discussion through a critical examination of the ways in which development studies have approached migration. He notes that migration and development discourses generally take the global South as the object of development, obscuring the transnational flows of labor and capital to the North, which serve to develop that region. Adopting the historical perspective that the authors of this special section share, he reviews previous moments at which migration was said to be key to the development of the South. This allows him to note how the current resurrection of migration as an agent of development is marked by the transnationalization of the model, with mobile people emerging as central agents of social transformation.

As does Glick Schiller, Faist reflexively asks, why now? Why have certain understandings of migration and development emerged at this particular historical conjuncture? Taking note of the intense contemporary interlinkages that are signaled by terms such as 'globalization', Faist suggests that an analysis of the actual contemporary relationships of power is needed, and this requires an alternative perspective on social transformation that cannot be contained within discussions of migration and development. He identifies the changing discourses on market, state and community, and the geo-political power structure as promising points of departure. Faist looks to an analysis of transnational social formations and places the possibility and limitations of migrants' agency within that framework.

Riina Isotalo begins her query into the current prominence of the topic of migration and development by speaking of the politicization of transnationalization. In her article, "Politicizing the Transnational: On Implications for Migrants, Refugees, and Scholarship," she notes that despite the fact that the initial scholarship on transnational migration was offered within a critique of uneven globalization, the paradigm has been taken up within current efforts to depict all human mobility as a threat to global and national security and as a prop for the faltering logic of neo-liberal free market development. Isotalo argues that the "developmentalization of mobility is not merely a consequence 
of the contemporary forces of capitalist restructuring but is as much related to the securitization of mobility."

In keeping with the emphasis of this special section on the historical contextualizing of social theory, Isotalo traces the way in which refugees have been configured in terms of security and economic development at various points in the twentieth century and up to the present time. Her article calls attention to the fact that "migration is now a part of security policies" (see also Faist 2003), a point only peripherally addressed by most migration scholars, who are caught up in discussions of migration integration and social cohesion within their own nation-states. The end result is that when the European Union talks about a "global approach on migration," the term 'global' is not deployed in the same way that Glick Schiller and other authors in this special section use it. While this special section speaks of 'the global' to address globe-spanning and locally constituting political and economic processes, imperial ambitions and projects, and social movements, both powerful Northern institutions, such as the European Union, and many migration scholars limit their global discussions primarily to remittance transfers for development needs and to security concerns linked to refugee flows across borders.

The question of the unit of analysis is central to Isotalo's approach to the politicization of both migrants' transnational connections and the development policies that highlight them. Isotalo notes that development and security discourses indulge in a form of "methodological individualism" in which individual migrants are highlighted as objects of scrutiny and as sources of remittances. This means that the broader social forces and institutional structures of power that have created the structural adjustment and neo-liberal environment and its instabilities - the forces that are highlighted by the authors of this special section-disappear from the analytic frame. Migrants fleeing from the so-called new wars that are produced by these instabilities are used as an "indicator of the lack of security." Containing migration then becomes key to ensuring security, and "migration management ... [becomes] a strategic matter of top priority in the European Union.” In adopting a global perspective on migration, Isotalo provides an innovative approach to the current discussion of remittances and development. She illustrates her argument by suggesting that the ways in which Palestinian rights are configured or denied in various areas of the Middle East shed light on more general approaches to the control of refugee flows, development, and security.

Raúl Delgado Wise and Humberto Márquez Covarrubias underscore Glick Schiller's and Faist's argument that any discussion of migration and development must begin by exploring the assumptions and units of analysis that underlie the project. In their article, "Understanding the Relationship between Migration and Development: Toward a New Theoretical Approach,” they situate their critique of contemporary migration and development discourses within a clearly articulated political economy of development, a perspective that they believe is generally lacking in migration scholarship. In offering this analytical stance, Delgado Wise and Márquez Covarrubias creatively build upon the work done within the last 40 years to develop and critique dependency theory, world-systems theory, 
and the political economy of neo-liberal globalization (England and Ward 2007; Frank 1969; Harvey 2005; Marini 1973; Rhodes 1970; Wallerstein 1979).

Delgado Wise and Márquez Covarrubias argue that discussions of migration and development must begin by acknowledging the inequalities that underlie migration flows. Noting the relationship between migration and efforts to restructure capital globally in line with neo-liberal agendas, they point out that the "great paradox of the migration-development agenda is that it leaves the principles that underpin neo-liberal globalization intact and does not affect the specific way in which neo-liberal policies are applied in migrant-sending countries." In centering their interest on migrant-sending countries, they offer a view from outside of North America and the European Union that is generally under-represented in migration and development discourse. As they point out, scholars in those regions, such as Bambirra (1978), Cardoso and Faletto (1969), Dos Santos (1974), Frank (1969), Furtado (1969), and Marini (1973), had stepped out of a methodological nationalist framing and utilized analyses of transnational processes to explain underdevelopment long before this critique emerged in the developed North.

From this stance, Delgado Wise and Márquez Covarrubias also are able to place migrant agency within broader social movements for transformation, offering not only a critique of the existing paradigm but an alternative framework and a vision of a means to facilitate the struggle for social and economic justice and equality. Rather than proffering a grand, homogenizing economic reductionist narrative, their framework examines the cultural power of dominant narratives, the specificity of regional arrangements, the dynamics and interpenetration between various geographic scales, and "a notion of development that surpasses the limitations of normative and decontextualized concepts and takes into account the necessary role of social transformation (i.e., structural, strategic, and institutional changes) in the improvement of living conditions among the general population."

In his article, "Adversary Analysis and the Quest for Global Development: Optimizing the Dynamic Conflict of Interest in the Transnational Divide of Migration," Binod Khadria confronts the win-win narratives with a view from the South. That positionality, developed over the course of centuries of colonial and neo-colonial inequalities, facilitates his queries into the relationship between the unequal economic, military, political, and cultural power of the North and the ways in which discourses about migration and development are framed. Khadria deconstructs the illusions about the equality of power between sending and receiving states by positioning them as adversaries. He calls for a dynamic understanding of the stakes and the stakeholders in the contemporary relationship between transnational processes including migration and the hierarchies of wealth and power between and within world regions and states. As is the case with the other authors in this special section, he asks global questions. Khadria wants to know what discussions of development would actually look like if we thought of the well-being of people around the world.

In pursuit of answers to these questions, Khadria refutes the widely made claims that the South benefits from return workers with enhanced skills, 
remittances, and technology transfers. He contrasts claims of benefits to the facts on the ground, such as those of patent regimes that tilt the flow of profits to the North when technology is adopted by the South. Rejecting the language of mutual benefit, Khadria begins a discussion of migration and development by acknowledging the adversarial relationship that exists between the regions. He argues that only when the actual situation is acknowledged, by taking the perspective of the other side into consideration, will it be possible to find common ground from which mutual good might be organized.

\section{Conclusion}

There is no doubt that, in principle, migration can produce outcomes that are beneficial to receiving countries, which attract 'global talent' by competing for the 'best and brightest' and which are also dependent on unskilled labor from abroad. These outcomes can be likewise beneficial to sending countries and the migrating populations, with their different class backgrounds and interests. Yet the conditions for realizing these benefits are complex because they are linked to transformations in the fundamental balance of power between regions and states and within states. Consequently, we view strategies that tout remittance-led development as being at best naive. This is so because migration alone cannot remove structural constraints to economic growth and greater democracy (Glick Schiller and Fouron 2001). The articles in this special section collectively emphasize the need for a many-pronged development strategy, in which the potential benefits of migration are small parts of larger plans to reduce inequality and to improve economic infrastructure, social welfare, and political governance.

In short, this special section, "Migration, Development, and Transnationalization: A Critical Stance," brings together a series of essays on migration and development that takes scholars and development practitioners beyond the blinders of the bulk of current migration and development theory and practice. We challenge those who are searching for ways to address the morass of development failure, vitriolic attacks on immigrants, or sanguine views about migrant agency to put aside their methodological nationalism and pursue alternative pathways into the topic that can lead us out of the quagmire of poverty, violence, and fear that seems to be enveloping the globe.

\section{Acknowledgments}

We would like to thank the Center for Interdisciplinary Research (ZiF, Zentrum für interdisziplinäre Forschung) at Bielefeld University, which sponsored the ZiF Cooperation Group, "Transnationalization and Development(s): Concepts and Venues for Research." Earlier versions of most contributions were presented and discussed in workshops of this group. 


\section{Notes}

1. See http://www.un.org/esa/population/migration/hld/index.html.

\section{References}

Bambirra, Vania. 1978. Teoría de la dependencia: Una anticrítica. Mexico City: Ediciones Era. Barth, Fredrik, ed. 1969. Ethnic Groups and Boundaries: The Social Organization of Culture Difference. Boston: Little Brown.

Brubaker, Rogers. 2004. Ethnicity without Groups. Cambridge, MA: Harvard University Press.

Cardoso, Fernando H., and Enzo Faletto. 1969. Dependencia y desarrollo en America Latina. Mexico City: Siglo XXI.

Dos Santos, Theotonio. 1974. Dependencia y cambio social. Buenos Aires: Amorrortu.

England, Kim, and Kevin Ward, eds. 2007. Neoliberalization: States, Networks, Peoples. Malden, MA: Blackwell.

Faist, Thomas. 2003. "Extension du domaine de la lutte: International Migration and Security." International Migration Review 36, no. 1: 7-14.

2008. "Migrants as Transnational Development Agents: An Inquiry into the Newest Round of the Migration-Development Nexus.” Population, Space and Place 14, no. 1: 21-42.

Frank, Andre Gunder. 1969. Latin America: Underdevelopment or Revolution. New York: Monthly Review Press.

Furtado, Celso. 1969. Desarrollo y subdesarrollo. Buenos Aires: Editorial Universitaria.

GCIM (Global Commission on International Migration). 2005. Migration in an Interconnected World: New Directions for Action. http://www.gcim.org/attachements/gcim-completereport-2005.pdf.

Glick Schiller, Nina. Forthcoming. "A Global Perspective on Transnational Migration: Migration without Methodological Nationalism." In Diaspora and Transnationalism: Concepts, Theories and Methods, ed. Rainer Bauböck and Thomas Faist. Amsterdam: University of Amsterdam and IMISCOE.

Glick Schiller, Nina, and Georges Fouron. 2001. Georges Woke Up Laughing: Long-Distance Nationalism and the Search for Home. Durham, NC: Duke University Press.

Guarnizo, Louis. 2003. "The Economics of Transnational Living." International Migration Review 37, no. 3: 666-699.

Harvey, David. 2005. A Brief History of Neoliberalism. New York: Oxford University Press.

Kapur, Devesh. 2004. "Remittances: The New Development Mantra?" G-24 Discussion Paper Series, No. 29. Washington, DC: World Bank.

Marini, Ruy Mauro. 1973. Dialéctica de la dependencia. Mexico City: Ediciones Era.

Nolin, Catherine. 2006. Transnational Ruptures: Gender and Forced Migration. Aldershot: Ashgate.

Ravenstein, Ernest G. 1885. “The Laws of Migration.” Journal of the Royal Statistical Society 48: $167-235$.

1889. "The Laws of Migration: Second Paper." Journal of the Royal Statistical Society 52: $241-305$.

Rhodes, Robert, ed. 1970. Imperialism and Underdevelopment: A Reader. New York: Monthly Review Press.

Siddiqui, Tasneem, ed. 2005. Migration and Development: Pro-Poor Policy Choices. Dhaka: University Press. Published in association with Great Britian's Department for International Development and Refugee and Migratory Movements Research Unit.

Sollors, Werner, ed. 1989. The Invention of Ethnicity. New York: Oxford University Press.

Thomas, William, and Florian Znaniecki. [1918-1920] 1958. The Polish Peasant in Europe and America. New York: Dover. 
Torpey, John. 2000. The Invention of the Passport: Surveillance, Citizenship and the State. Cambridge: Cambridge University Press.

UNDP (United Nations Development Programme). 2009. Overcoming Barriers: Human Mobility and Development. http://hdr.undp.org/en/media/HDR_2009_EN_Complete.pdf. Vertovec, Steven. 2007. "Circular Migration: The Way Forward in Global Policy?" Working Papers \#4, International Migration Institute, Oxford University. http://www.imi.ox.ac. uk/pdfs/wp4-circular-migration-policy.pdf.

Wallerstein, Immanuel. 1979. The Capitalist World-Economy. Cambridge: Cambridge University Press.

World Bank. 2002. Globalization, Growth, and Poverty. Washington, DC: World Bank. . 2006. Global Economic Prospects 2006: Economic Implications of Remittances and Migration. Washington, DC: World Bank. 